\title{
Implications of Decreasing Farm Size on Urbanization: A Case Study of Punjab Pakistan
}

\author{
Umar Mukthar \\ College of Economics and Management, Huazhong Agricultural University, No.1, \\ Shizishan Street, Hongshan District, Wuhan, Hubei Province, 430070, P.R. China. \\ Tel: 86-130-261-7362. E-mail: umarmukhtar312@yahoo.com
}

\section{Zhong Zhangbao}

Corresponding Author: College of Humanities and Social Sciences, Huazhong Agricultural University, No.1, Shizishan Street, Hongshan District, Wuhan, Hubei Province, 430070, P.R. China. Tel: 86-139-710-0516. E-mail: zzbemail@mail.hzau.edu.cn

\section{Tian Beihai}

College of Humanities and Social Sciences, Huazhong Agricultural University, No.1, Shizishan Street, Hongshan District, Wuhan, Hubei Province, 430070, P.R. China.

Tel: 86-27-8728-0005. E-mail: tianbeihai@mail.hzau.edu.cn

\section{Muhammad Asad Ur Rehman Naseer}

Institue of Agricultural and Resource Economics, University of Agriculture Faisalabad, Punjab Province, 38000, Pakistan. Tel: 923-146-107-745. E-mail: asadlaysa@hotmail.com

\section{Amar Razzaq}

College of Economics and Management, Huazhong Agricultural University, No.1, Shizishan Street, Hongshan District, Wuhan, Hubei Province, 430070, P.R. China.

Tel: 86-150-7249-2965. E-mail: amar.razzaq@hotmail.com

\section{Tayyaba Hina}

Institue of Agricultural and Resource Economics, University of Agriculture Faisalabad, Punjab Province, 38000, Pakistan.

Tel: 923-466-988-806. E-mail: tayyaba_hina@outlook.com 


\section{Mll Macrothink}

Received: January 10, 2018 Accepted: April 27, 2018 Published: April 29, 2018

doi: $10.5296 /$ jsss.v5i2.12746

URL: http://doi.org/10.5296/jsss.v5i2.12746
Journal of Social Science Studies

ISSN 2329-9150

2018, Vol. 5, No. 2

\begin{abstract}
The rate of urbanization in Pakistan especially in Punjab is quite high. The reason behind this is the high population growth that is about 2.4 percent in the last decade. This causes a burden on the farm size and in rural areas people have no choice except to move in the urban areas for their livelihood. The main objective of this study was to identify the key influential factors that affect the decision to migrate. Study evaluated the impact of economic, social, demographic, natural and climatic factors on the welfare of the migrants and non-migrant's households. For this purpose, an extensive survey from 504 respondents was carried out in four districts of Punjab, Pakistan. Due to the dichotomous nature of the dependent variable i.e. migrant and non-migrant, logistic regression was employed on the collected data using Stata. Results revealed that unemployment, educational and health facilities, family conflicts, small farm size for agricultural activities, and greater family size are the main influencing factors affecting migration decision from rural to urban areas. This creates the strong implications i.e. putting burden on the urban areas due to the high rate of urbanization. So, it is however recommended to stem down the rate of migration all necessary facilities should be provided in the rural areas and Agro-based must be set up near the rural areas providing employment opportunities for the rural dwellers.
\end{abstract}

Keywords: Urbanization, Migration Decision, Farm Size, Rural Livelihood, Logistic Regression

\title{
1. Introduction
}

Pakistan is the $10^{\text {th }}$ largest labor force country with an estimated population of almost 208 million (PBS, 2017). Total population of Pakistan's economy shows positive growth that increased almost 57 percent by considering 1998 as a base year excluding Azad and Jammu Kashmir and Gilgit Baltistan. According to 2017 census, urban population has been increased to 36.38 percent of total population and rural population has been decreased from 65.6 percent to 63.6 percent due to migration of rural people from rural areas to urban areas or urbanization (PBS, 2017; Ishfaq et al., 2017). Urbanization in Pakistan is rapidly growing due to population growth, rural to urban migration and refugees' migration (Business Recorder, 2017). The other reason for urbanization is the decreasing farm size in rural areas putting a burden on the agricultural setting of the rural households (Naseer et al., 2016; Regmi, 2014; Bhatta, 2010; Alonso, 1964).

According to the Population Census of Pakistan 2017, the urban population depicted an increasing trend with 38.8 percent of the population living in the urban areas. The comparative position of the provinces and area showed similar trends in urban population with a slightly higher increase in the Punjab. On the other hand, a significant decrease has been observed of urban population in the ICT which gone from 65.72 percent to 50.58 percent, indicating a growth of population in rural areas of Islamabad. Among the provinces, 
Sindh is the most urbanized province where 52.02 percent population is living in urban areas (PBS, 2017).

Table 1. Trend of Urbanization in Pakistan: Province wise

\begin{tabular}{lcccccc}
\hline \multirow{2}{*}{ Admin Unit } & \multicolumn{3}{c}{ Population (million) } & \multicolumn{3}{c}{ Urban Share \% } \\
\cline { 2 - 7 } Pakistan & 1981 & 1998 & 2017 & 1981 & 1998 & 2017 \\
KP & 84.25 & 132.35 & 207.77 & 28.3 & 32.52 & 36.38 \\
FATA & 11.06 & 17.74 & 30.52 & 15.06 & 16.87 & 18.77 \\
Punjab & 2.2 & 3.18 & 5 & - & 2.69 & 2.84 \\
Sindh & 47.29 & 73.62 & 110.01 & 27.6 & 31.27 & 36.71 \\
Baluchistan & 19.03 & 30.44 & 47.89 & 43.32 & 48.75 & 52.02 \\
Islamabad & 4.33 & 6.57 & 12.34 & 15.62 & 23.89 & 27.55 \\
\hline
\end{tabular}

Source: Pakistan Bureau of Statistics, 2017.

Migrants are mostly move from low propensity (Push factors) areas to high propensity (Pull factors) areas due to get greater benefits related to health, education and employment and their movement has high influence on non-migrants (Bayoh et al., 2006; Kainth, 2010; Abdul-Azeez \& Opoola, 2011). Rural-urban migration has greatly affected the rural economy growth and food security due to migration of young labor to cities and decreased the productivity of rural sector (Crow, 2010; Mora \& Taylor, 2006). The decision of people from rural to urban areas are based on the pull factors to attract them and push factors to attract the people to migrate (Abdul-Azeez \& Opoola, 2011). People continues to migrate until the wages of rural labor and urban labor not equalized. Mostly, lack of employment opportunities, lack of land, lack of rural credit and rural poverty force them to migrate for better employment opportunities and higher wages for the rural dwellers (Lagakos et al., 2017; Gans, 1968).

Migration is a selective process, the characteristics of people migrate and already living people are much more different from each other. Education (no. of schooling) has positive impact on the migration from traditional agriculture sector to modern sector (Adams \& Richard, 2003). Pakistan is a developing country where migration within the country is the key driver of economic growth of all sectors such as agriculture, industrial, services and construction sector. This is an effective tool for the policy makers to reduce income inequality among the rich and poor as well as reduce the poverty in rural areas (Ishfaq et al., 2017).

There are various socio-economic and demographic factors that influence the migration from rural to urban areas. The first category of factors includes the age, occupation, marital status, crime rate, conflicts and social amenities. The second factor includes the job opportunities in urban areas, lack of industries, educational facilities and low level of agricultural productivity (Tacoli et al., 2015).

In Pakistan, migration of rural people to cities is seasonal in nature and people come back to 
agriculture sector for harvesting of crops. This phenomenon is causing a fundamental problem of labor shortage in modern sector and agriculture sector during this time period. Migration of rural people to urban areas is causing a severe problem not only for rural areas as well as for urban communities. Migration decision has been influenced by many socio-economic and demographic factors that has also affected the livelihoods of family (Danejo et al., 2015). This study aims to identify the key influential factors affecting the decisions related to migration and its impact on the welfare of the migrants and non-migrant's households.

\section{Review of Literature}

Rural urban migration is a very common and attractive phenomenon in the developing countries. Due to the agricultural and rural base of the developing countries, its most of the people lives in rural areas. The industrialization of the $21^{\text {th }}$ century putting burden in the cities and people starts moving from their native places to the urban cities due to several reasons. In this section we tried to look these factors highlighted previously by various researchers specialized in developing economies.

Melo and Ames (2016) identified the driving economic factors of rural-urban migration and its impact on agricultural labor force in China. They used panel data and collected from the National Bureau of Statistics of China 2014 to identify the key factors of migration. They used the ARDL-type Dynamic Panel Data model to assess the impact of identified economic factors on agricultural work force. The co-efficient of modern sector shoed that by decreasing 1 percent wage rate in this sector had increased 0.3 percent workforce of agriculture sector. The co-efficient of construction sector showed that by decreasing the 1 percent wage rate in construction sector had increased 0.3 percent the work force in agricultural sector. They concluded that low-income people of rural areas were mostly move towards the urban areas for getting jobs in industrial sector and higher income to support own families.

Abdul-Azeez and Opoola (2011) identified the factors that affected the internal migration and assessed the benefits drive from rural-urban migration. This study was carried out in Lagos of Nigeria. A sample size of 400 respondents were selected randomly from 6 Local Government Areas (LGAs). A pre-tested survey guide was used to collect the information from selected respondents. A linear Logistic regression model was used to analyze the data. Results indicated that by increasing 1 -year schooling (education) the log-odd of rural urban migration had increased by 1.6014 , by keeping the effect of all other independent variables constant that was statistically significant at 5 percent level of significance. The co-efficient of unemployment showed that by increasing the 1-unit employment had increased the 8.1744 log-odd of rural urban migration by keeping the effect of all other explanatory variables constant that was also statistically significant at 5 percent. The parameter of health showed that by increasing the 1 unit of health had increased the log-odd of internal migration by 0.3835 units by keeping the effect of all other independent variables constant. They concluded that rural urban migration not only affect the rural community but also affect the urban community. They suggested that provision of all basic health, education, electricity and employment opportunities would be helpful to control the rural-urban migration.

Khan et al. (2011) analyzed the total and gender wise causes of rural to urban migration. This study was carried out among the states and Union Territories (UTs) in India and used the 
secondary data for further analysis. Secondary data were collected from Census of India, 2001. They grouped the reasons into 7 categories that was business, employment, marriage, education, moved with households, moved after birth and others. Results revealed that 70.6 percent migrants were migrated due to social factors and gender wise mostly male were migrated as compare to females. They also showed that 52.3 percent male and 5.7 percent females were migrated due to economic factors. They concluded that 52.2 percent people were migrated for long time from 4 states and 6 UTs due to employment opportunities and people also moved from rural to urban areas for fleeting time due to migration of family.

Ajaero and Onokala (2013) assessed the effects of rural-urban migration on rural community south eastern areas of Nigeria. This study was carried out in six Local Government Areas (LGAs) and 50 respondents were selected from each LGA. A well-structured questionnaire was used to collect the information. Multiple Regression model and Hierarchal cluster analysis were used for data analysis. They also used the Chi-square and Kruskal-Wallis test to prioritize the areas of development. Results revealed that by increasing 0.054 unit use of remittances for training of children had increased the rural to urban migration by keeping all other factors constant. Results indicated that migration of rural to urban areas contributed towards the development of rural economy through remittances and involvement of migrants in various rural community development projects. They recommended that dependency on the monetary remittances would be decreased by increasing the productive capacity of agriculture sector.

Ali et al. (2015) identified the pull and push factors of rural-urban migration and evaluated the impact of rural-urban migration of household incomes in district Peshawar, Khyber Pakhtunkhwa, Pakistan. This study was carried out in 2 villages namely Wazir colony and Latifabad where almost 930 migrants were living and only 10 percent were selected by using Roscoe sampling formula for this study. A paired t-test was used to check the income difference of selected respondents before and after migration. Results revealed that income of selected respondents had increased after migration. There were only 5.4 percent respondents that had higher income above 24 thousand, 18.3 percent had 16001 to 24 thousand incomes, 35.5 percent had income from 8 thousand to 16 thousand and 40 percent had income below 8 thousand before migration. After migration, there were 19.3 percent respondents had above 24 thousand incomes, 39.8 percent had income from 16001 to 24 thousand, 28 percent had income from 8001 to 16 thousand and 12.9 percent respondents had income up to 8000 . They recommended that basic facilities like education, health and creation of off-farm jobs, improved training opportunities and development programs should be provided to rural people.

Danejo et al. (2015) identified the socio-economic factors that affect the decisions related to rural-urban migration and evaluated the income generated by the migrants in Nigeria. This study was carried out in 3 wards of Wukari LGA of Taraba state, Nigeria. A sample size of 60 respondents were selected randomly and collected information from respondents by using well-structured questionnaire. Secondary data were collected from books, journals, student projects and seminars. Descriptive statistics and Chi-square method were used to analyze the collected raw-information. They identified that age, occupation and marital status were major socio-economic factors affecting the rural-urban migration. Findings showed that 93.3 
percent respondents were migrated due to conflicts, 63.3 percent respondents were migrated due to find a better job, 48.3 percent were migrated due to lack of social facilities, 26.6 percent were migrated due to crop failure and famine, 56.7 percent were migrated for improving his livelihoods condition and 35 percent were migrated for learning and improving trade skills. Chi-square results showed that there was a significant relationship between the age and lack of infrastructure that guaranteed to move from rural to urban areas. Results also revealed that there was a significant relationship exist among the education level and job opportunities in urban areas.

\subsection{Theoretical Framework}

Relevant literature suggests that there are four factors affecting rural to urban migrations as shown in a schematic diagram figure 1. The first set is related to the economic factors including employment, farm size and access to resources. The second set is related to the social factor that is family structure, religious or ethnic conflicts, and social services and amenities. The third set of factors are demographic i.e. age, gender, education and population growth. The fourth set of factors is related to the natural disaster and climate change. The economic and social set of factors are common in the literature for the movement of rural dwellers to the urban cities (Mabawonku, 1973; Sabot, 1972; Abdul-Azeez, 2011; Lerman, 1975).

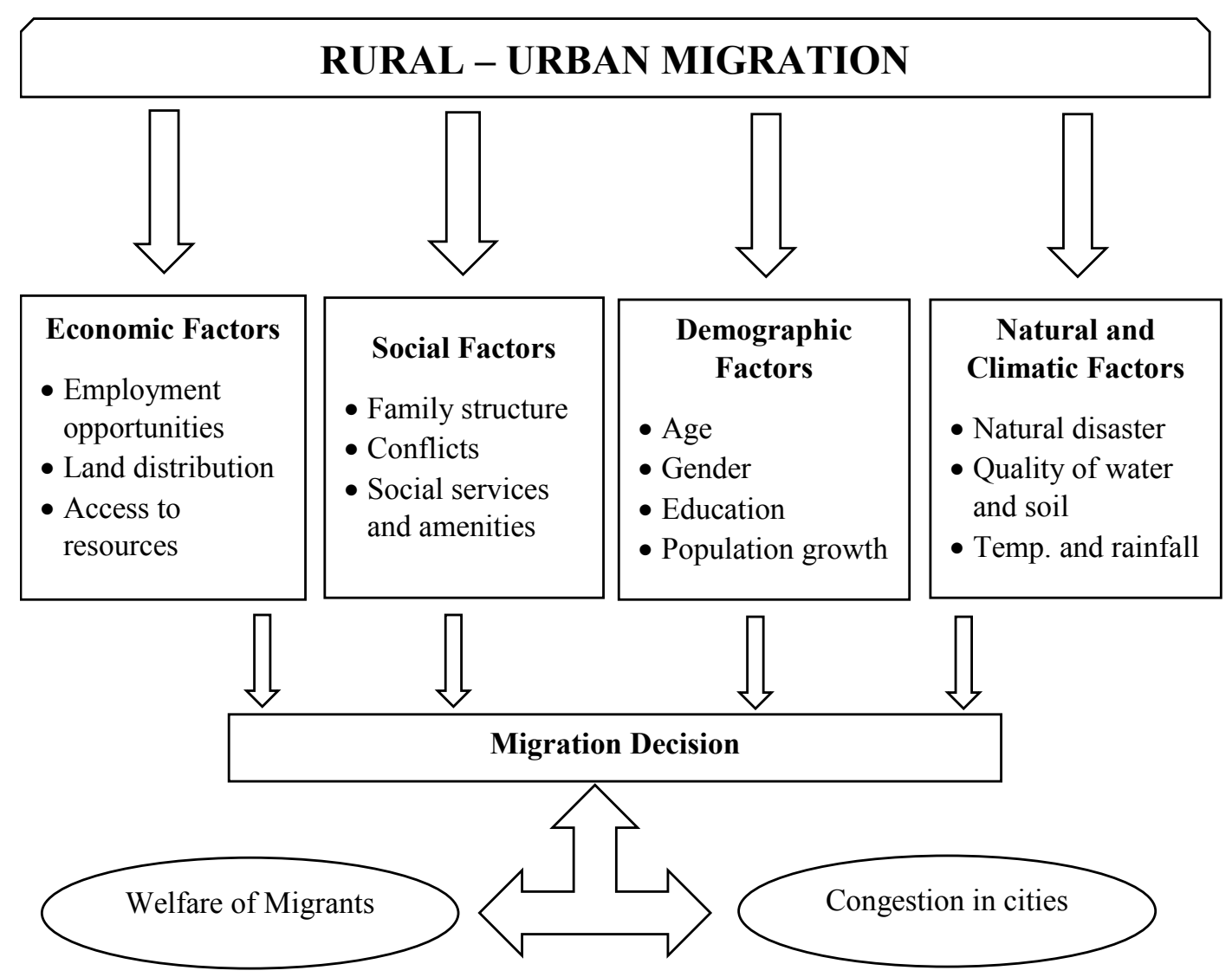

Figure 1. Theoretical framework of the Study

\section{Methodology}


Methodology is an effective tool which guides the researcher to collect, analyze and interpretation of the data. Research design is a set of strategies that enables the researchers to provide a solution to encounter the problems faced during research (Lewis, 2015).

\subsection{Description of Study Area}

This study was conducted in Punjab, Pakistan. Punjab is the most populous province with an estimated population of 110.01 million during 2017 population census of Pakistan that is about 52.95 percent of the total population in the country. Pakistan is in the list of fast urbanizing country in the world. The rate of urbanization in Punjab is 36.71 percent (PBS, 2017). The reason of urbanization is decreasing land size in rural areas and high population growth i.e. more than 2 percent (GOP, 2017). Punjab is also more industrialized province as compare to other provinces. The urban growth in cities like Lahore, Faisalabad, Gujranwala, Sialkot, Sheikhupura and Rawalpindi is very high. Present study was carried out in 4 districts i.e. Lahore, Faisalabad, Gujranwala and Sialkot of Punjab, Pakistan. The rural urban population in the selected districts is shown in Table 2.

Table 2. Percentage of rural urban population in the study area

\begin{tabular}{lcccc}
\hline \multirow{2}{*}{ Area } & \multicolumn{2}{c}{ Population Census 1998 } & \multicolumn{2}{c}{ Population Census 2017 } \\
\cline { 2 - 5 } Pakistan & Rural & Urban & Rural & Urban \\
Punjab & 65.6 & 34.4 & 63.6 & 36.4 \\
Lahore & 67.2 & 32.8 & 63.3 & 36.7 \\
Faisalabad & 17.8 & 82.2 & 0.0 & 100.0 \\
Gujranwala & 57.3 & 42.7 & 52.2 & 47.8 \\
Silakot & 44.8 & 55.2 & 41.2 & 58.8 \\
\hline
\end{tabular}

Source: Pakistan Bureau of Statistics, 2017.

\subsection{Sample size and Data Collection}

A multistage random sampling technique was used to select a sample size. At first stage, 4 districts i.e. Lahore, Faisalabad, Gujranwala and Sialkot of Punjab were selected and at second stage 63 respondents were selected from rural areas of each 4 selected districts. A sample size of total 504 (252 migrants and 252 non-migrants) respondents were selected through random sampling technique. Data were collected through personal interview survey. For this purpose, a questionnaire was developed to collect the purposive information from selected respondents. A questionnaire was composed of information regarding identification of socio-economic factors of migration and its impact on welfare of migrants and non-migrant's households. A test survey was conducted to check the workability of questionnaire on 10 randomly selected respondents from rural area. A well-structure questionnaire was used to collect information after pre-testing. After pre-testing appropriate changes were made in the questionnaire and final survey was conducted in study area to collect the required information from selected respondents. 


\subsection{Econometric Technique}

the logistic regression model was used to check the determinants behind migration decision. The logistic regression was used due to the binary data that linear multiple regression failed to analyze effectively. Unlike linear multiple regression model, the logistic regression model forces the estimated probabilities to lie with the range of $0-1$ [Bryan (1994); Abdul-Azeez (2011)]. The estimated probability lies between 0 and 1. The mathematical expression of logistic regression model is as follows;

$$
\operatorname{Ln}\left(\frac{\mathrm{PI}}{1-\mathrm{P} 1}\right)=\beta_{0}+\beta_{1} X_{1}+\beta_{2} X_{2}----\beta_{k} X_{k}+\varepsilon_{i}
$$

The odds ratio of the probability for a household person to migrate or not in the urban centers was calculated using logit model as;

$$
\begin{gathered}
P_{i}=E\left(Y=1 \mid X_{i}\right)=\left[\frac{1}{\left.1+e^{-\left(\beta_{\theta}+\beta_{t} 2 X_{i}+\theta_{n}\right)}\right]}\right] \\
L_{i}=L_{n}\left(\frac{P_{i}}{1-P_{i}}\right)=\beta_{Q}+\beta_{1} \sum X_{i}+\varepsilon_{i}
\end{gathered}
$$

where Li (logit) is the log of the odd ratios and is linear in both independent variables and parameters. The estimation method to be used was the maximum likelihood estimator (MLE).

\subsection{Description of the Variables}

\subsubsection{Dependent Variable}

- 0 for non-migrant and 1 for migrant

3.4.2 Independent variables

- Age of respondents (migrant person) in years

- Education of respondents (migrant person) in schooling years

- Income of the household in rupees

- Job Opportunities in the rural area (" 0 " if yes otherwise " 1 ")

- Educational facilities in the rural area ("0" if yes otherwise " 1 ")

- Health facilities in the rural area (" 0 " if yes otherwise " 1 ")

- Family Structure ("0" if nuclear otherwise " 1 ")

- Owned agricultural land size in acres

- Conflicts i.e. Ethnical or Religious (" 0 " if yes otherwise " 1 ”)

- Security reason ("0" if yes otherwise " 1 ")

- Distance from nearest city in kilometers

- Number of bed rooms per person in the rural home

- Family Size of the rural household

- Natural calamities i.e. Flood, Famine, Earthquake (“0” if yes otherwise "1") 


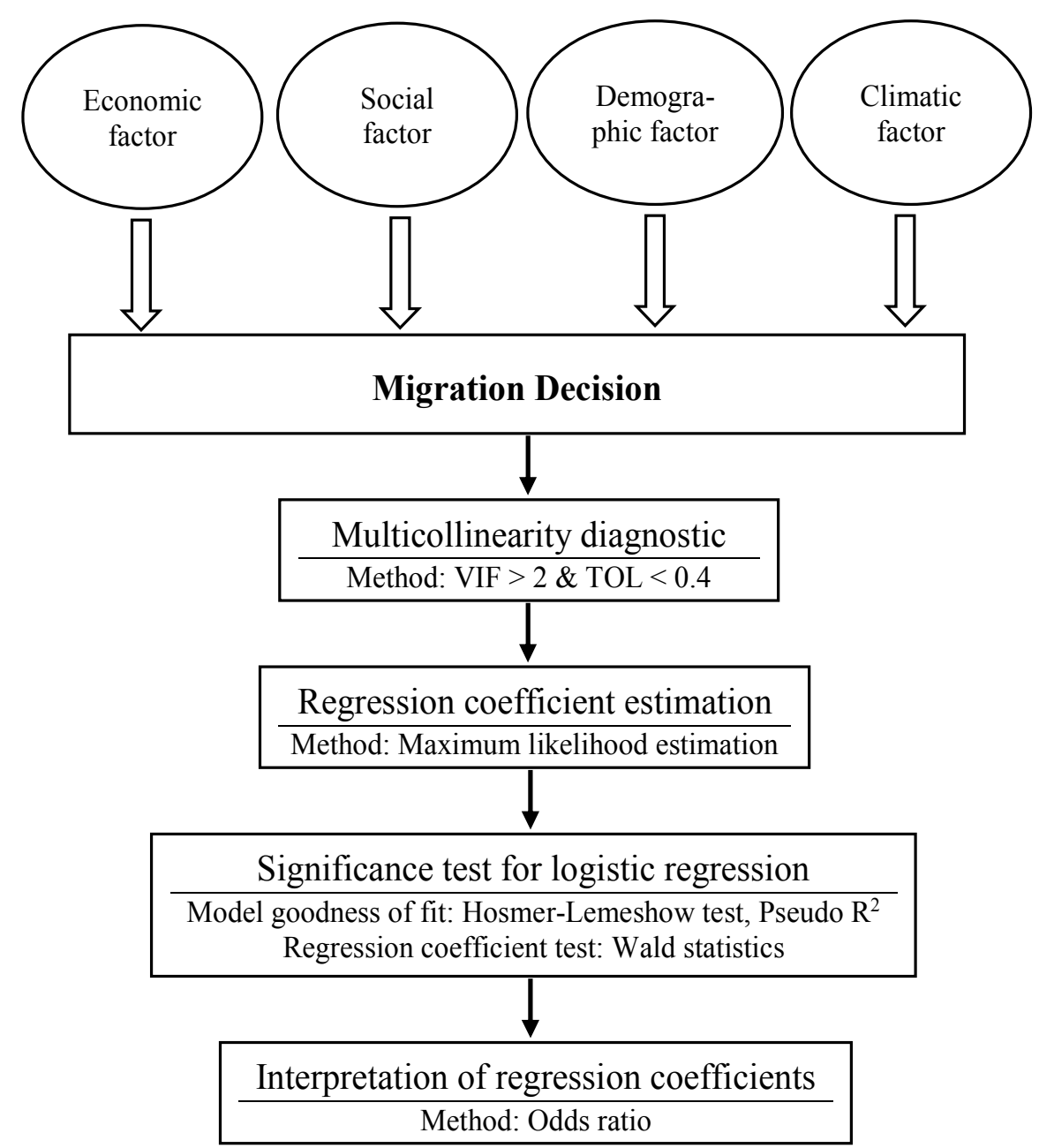

Figure 2. Construction process of econometric analysis

\section{Results and Discussion}

In this section, the results of the study analysis using the primary dataset of migrant and non-migrant households are presented. In the first part of this section, descriptive analysis of the respondents is presented. In the second part, the econometric results of the logistic regression are discussed.

\subsection{Descriptive Statistics}

The selected descriptive results illustrated important characteristics of the migrants and the migration process that can support some of the underlying hypotheses of the study, it also helped to qualify variables used for the modeling exercise. Summary statistics of household characteristics comparing migrant and non-migrant households are showed in Table 3. Some variables which statistically significant differences in mean. The most important variable of our study is the land size, shows that migrant household have smaller farm size as compared with the non-migrant households. Migrant households have smaller family size Migrant households have more educated household members. This supports the notion of human capital drain from rural to urban areas. The average income of the migrant households is greater than non-migrant households. This is because of the remittances, migrant person supports their families also found by Reda et al. (2012). 
Table 3. Households' characteristics of the respondents

\begin{tabular}{ccccccc}
\hline Variable & Household & Min. & Max. & Mean & Std. Dev. & Diff. Sig. \\
\hline Family & Migrant & 2 & 7 & 4.35 & 0.773 & \\
Size & Non-Migrant & 1 & 8 & 4.54 & 0.969 & .019 \\
$\begin{array}{c}\text { No.) } \\
\text { Farm Size }\end{array}$ & Migrant & 0 & 8 & 1.29 & 1.706 & .025 \\
$\begin{array}{c}\text { Acres) } \\
\text { House Size }\end{array}$ & Non-Migrant & 0 & 10 & 1.48 & 1.820 & \\
$\begin{array}{c}\text { (No.) } \\
\text { No. of Bed }\end{array}$ & Non-Migrant & 3 & 10 & 6.27 & 1.800 & .037 \\
$\begin{array}{c}\text { Rooms per } \\
\text { person }\end{array}$ & Mon-Migrant & 0.20 & 1.33 & 0.53 & 0.125 & \\
Income & Migrant & 0.12 & 1.33 & 0.56 & 0.213 & .156 \\
$(000$ 'Rs $)$ & Non-Migrant & 9 & 50 & 17.38 & 5.147 & .202 \\
\hline
\end{tabular}

Source: Survey Results,

Table 4 revealed that access to social amenities i.e. physical infrastructure the household possess for both migrant and non-migrant. It can be seen from the table that migrant households possess own house lesser than the non-migrants. Similarly, migrant households possess lesser facilities such as health, education and recreational. It means this affect the migration decision, by providing these facilities at rural level the urban sprawl will become not so fast. So, our Government should take steps to provide all basic facilities at rural level.

Table 4. Access to social amenities in percentages

\begin{tabular}{cccc}
\hline Facility & Response & Migrants & Non-migrants \\
\hline Owned House & Yes & 98 & 100 \\
$(\%)$ & No & 2 & 0.00 \\
Educational & Yes & 44 & 49 \\
$(\%)$ & No & 56 & 51 \\
Health & Yes & 43 & 52 \\
$(\%)$ & No & 57 & 48 \\
Religious & Yes & 100 & 100 \\
$(\%)$ & No & 0.00 & 0.00 \\
Recreational & Yes & 62 & 68 \\
& No & 38 & 32 \\
\hline
\end{tabular}

Source: Survey Results. 


\subsection{Results of the Logistic Regression}

The estimated logistic regression model (LR) for this study has been approved mathematically through the relevant tests such as likelihood ratio test, Hosmer-Lemeshow test, significance test (Hosmer et al., 2013), which validates that this model is reliable, and the model parameters are statistically significant. The results of the VIF and TOL values revealed that the multicollinearity did not exist in the studied model for explaining the determinants of urban migration as showed in Table 5.

Table 5. Results for the multicollinearity statistics

\begin{tabular}{ccc}
\hline Independent Variables & TOL & VIF \\
\hline Age & 0.86 & 1.16 \\
Education & 0.89 & 1.13 \\
Income & 0.96 & 1.04 \\
Job Opportunities & 0.97 & 1.03 \\
Educational Facilities & 0.88 & 1.14 \\
Health Facilities & 0.90 & 1.12 \\
Family Structure & 0.96 & 1.04 \\
Land Size & 0.47 & 2.11 \\
Conflicts & 0.97 & 1.04 \\
Security Reasons & 0.93 & 1.07 \\
Distance from City & 0.92 & 1.09 \\
Rooms per Person & 0.86 & 1.16 \\
Family Size & 0.89 & 1.12 \\
Natural Calamities & 0.98 & 1.02 \\
Agricultural Household & 0.46 & 2.16 \\
\hline
\end{tabular}

Source: SPSS 23 output of the data analysis.

The results of the goodness of fit of the regression model (showed in Table 6) suggested that the independent variables can explain the target variable to some degree. The Nagelkerke's $\mathrm{R}^{2}$ value is 0.392 , i.e. the model explains $39.2 \%$ of changeability in the dependent variable migration decision, explained by the selected independent variables.

Table 6: Goodness of fit test of the rare events logistic regression model

\begin{tabular}{|c|c|c|c|c|}
\hline \multicolumn{2}{|c|}{ Hosmer-Lemeshow test } & \multirow[b]{2}{*}{-2 Log likelihood } & \multirow{2}{*}{ Cox \& Snell R ${ }^{2}$} & \multirow{2}{*}{ Nagelkerke $\mathrm{R}^{2}$} \\
\hline$X^{2}$ & Sig. & & & \\
\hline 4.767 & 0.782 & 38.931 & 0.317 & 0.392 \\
\hline
\end{tabular}

Source: SPSS 23 output of the data analysis.

The focus of this study was on the agricultural land size on migration decision, so to 
categorize the respondents' possession of agricultural land is used as categorical variable in studied model. The distribution of agricultural and non-agricultural households in shown in Table 7.

Table 7. Agricultural land: Categorical variable coding

\begin{tabular}{ccc}
\hline Possession of Agri. Land & Frequency & Parameter coding (1) \\
\hline Yes & 221 & 1 \\
No & 279 & 0 \\
\hline
\end{tabular}

Source: SPSS 23 output of the data analysis.

In this model, the probability of being a migrant is denoted by $\mathrm{P}$, that is regarded as a function of the behavior of different social, economic, demographic, climatic and natural factors which is equivalent to the uncertainty a target belongs to one of the two defined groups. Taking the probability of households' migration decision as a new classification index (the classification threshold value is 0.5 ), the overall classification accuracy of the model is $66.8 \%$ as shown in Table 8.

Table 8. Classification table ${ }^{\text {a }}$

\begin{tabular}{cccc}
\hline \multirow{2}{*}{ Observed } & \multicolumn{2}{c}{ Predicted } & Percentage Correct \\
\cline { 2 - 3 } Non-migrant & 217 & Migrant & \\
Migrant & 101 & 65 & 77 \\
& Overall Percentage & 117 & 53.7 \\
& & & 66.8 \\
\hline
\end{tabular}

a. The cut value is 0.50 .

Source: SPSS 23 output of the data analysis.

The results of the estimated logistic regression coefficients and their corresponding statistical indicator's significance are listed in Table 9. To verify the statistical significance of the estimated parameters, study used the Wald test. If the p-value is lower that the considered significance level, the zero hypothesis is rejected in favor of the alternative hypothesis. The results indicated that income, job opportunities, rooms per person and natural calamities are statistically insignificant ( $\mathrm{p}$-value $>\alpha$ ). All other parameters are statistically significant, that means they have significant impact on the households' migration decision to move from rural to urban areas.

The logistic regression model indicated that if the value of continuous variable i.e. Age, increase in one unit, the logistic change in the value of the coefficient of -0.024 . The exp. $(-0.024)=0.976$-times less probability to migrate, that means younger people are more concerned to move in the cities. Conversely, Age has positive impact on the migration decision as the chances of one-unit higher education increase the probability to migrate by 1.083 times. The basic facilities of education and health are used as a binary response independent variable in this study, which means that if the households have not access to 
these facilities then the probability to migrate will increase by 1.79 and 1.85 times respectively for educational and health facilities.

Table 9. Determinants of migration decision: Results of the logistic regression analysis

\begin{tabular}{cccccc}
\hline Determinants & B & S.E. & Wald & Sig. & Exp.(B) \\
\hline Age & -0.024 & 0.010 & 5.576 & $0.018^{* *}$ & 0.976 \\
Education & 0.080 & 0.035 & 5.324 & $0.021^{* *}$ & 1.083 \\
Income & 0.011 & 0.016 & 0.511 & $0.475^{\mathrm{NS}}$ & 1.011 \\
Job Opportunities & 0.180 & 0.207 & 0.753 & $0.386^{\mathrm{NS}}$ & 1.197 \\
Educational Facilities & 0.584 & 0.210 & 7.746 & $0.005^{* * *}$ & 1.793 \\
Health Facilities & 0.615 & 0.212 & 8.448 & $0.004^{* * *}$ & 1.850 \\
Family Structure & -0.960 & 0.199 & 23.349 & $0.000^{* * *}$ & 0.383 \\
Land Size & -0.102 & 0.083 & 1.524 & $0.021^{* *}$ & 0.903 \\
Conflicts & -0.340 & 0.315 & 1.164 & $0.028^{* *}$ & 0.712 \\
Security Reasons & 0.127 & 0.204 & 0.389 & $0.053^{*}$ & 1.135 \\
Distance from City & -0.039 & 0.011 & 11.463 & $0.001^{* * *}$ & 0.962 \\
Rooms per Person & 0.380 & 0.504 & 0.570 & $0.450^{\text {NS }}$ & 1.462 \\
Family Size & -0.248 & 0.120 & 4.305 & $0.038^{* *}$ & 0.780 \\
Natural Calamities & -0.017 & 0.314 & 0.003 & $0.957^{\text {NS }}$ & 0.983 \\
Agri. Land (1) & -0.422 & 0.292 & 2.092 & $0.014^{* *}$ & 0.656 \\
Constant & 0.779 & 1.112 & 0.491 & $0.484^{\text {NS }}$ & 2.179 \\
\hline
\end{tabular}

Dependent variable: Probability of being a migrant; d. f. $=1$

***** , ${ }^{*}$ and ${ }^{\mathrm{NS}}$ significant at 1\%,5\%,10\% and non-significant respectively.

Source: SPSS 23 output of the data analysis.

Results of our regression analysis also revealed that joint family have lower probability i.e. 0.383 times that the nuclear families. The role of security situation in the rural areas is also very important according to our regression results and have significant impact on the migration decision, if the security situation is not good the probability to migrate will increase by 1.135 times. The households from the remote areas have lesser chances to migrate, as coefficient value of distance has negative sign indicated that by an increase in one unit of distance probability to migrate will decrease by 0.962 times. Family size have a negative impact on the migration decision i.e. by increasing one person the probability to migrate will be exp. $(-0.248)=0.780$ times less.

The important variable being used in this model is the land size and agricultural and non-agricultural households. The independent variable of land size shows a significant impact on the migration decision, by a unit increase in the land size will reduce the chances to migrate by 0.903 times. This means the small farm size household tends more to migrate in the urban areas. Study also used the possession of agricultural land as a categorical variable, the regression results of this variable also have significant impact on the migration decision. The households that possess agricultural land have less probability to migrate in the urban cities by exp. $(0.422)=0.656$ times. 


\section{Conclusion and Recommendation}

The study presents an empirical evidence from Punjab-Pakistan on the effects of rural to urban migration using a primary data of 500 respondents. Among various attributes of migrants, the prominent one is that the persons who tend to migrate are those who are no longer interested in developing agricultural sources of livelihood and that's why rely on remittances. Migration usually increase the inequality in rural households, as the better households incline to have successful migrants, as the more educated personas are sent away, even though it doesn't go with the idea of poor education quality in rural areas.

Results revealed that unemployment, family conflicts, small farm size for agricultural activities, poor educational and health facilities, and large family size are the main influencing factors which prompt migration decision from rural to urban areas. Hence, creating a growing burden on urban centers to bear.

To lower down the pace of growing trend of urbanization in larger cities it is the need of the hour to provide better educational and health facilities. Also create better employment opportunities by executing the idea of evolving agro-based small industrial sectors in rural areas, which will reduce the post-harvest losses of various crops (perishable) as well as create handsome employment opportunities.

\section{References}

Abdul-Azeez, I. A., \& Opoola, N. A. (2011). An appraisal of the factors influencing rural-urban migration in some selected local government areas of Lagos State Nigeria. Journal of sustainable Development, 4(3), 136.

Adams, Jr., \& Richard, H. (2003). International Migration, Remittances \& the Brain Drain: A Study of 24 Labor-Exporting Countries. World Bank Policy Research Working Paper 3069, June 2003. http://hdl.handle.net/10986/18161

Ajaero, C. K., \& Onokala, P. C. (2013). The effects of rural-urban migration on rural communities of southeastern Nigeria. International Journal of Population Research

Ali, H., Shafi, M., Rehman, U., \& Jadoon, M. A. (2015). Causes \& Effects of Rural-Urban Migration in Rural Areas of Khyber Pakhtunkhwa-Pakistan. Arts Social Sci J., 6(5).

Alonso, W. (1964). Location \& Land Use, Toward a General Theory of Land Rent, Harvard University Press. Cambridge. https://doi.org/10.4159/harvard.9780674730854

Bayoh, I., Irwin, E. G., \& Habb, T. (2006). Determinants of Residential Location Choice: How Important Are Local Public Goods in Attracting Homeowners to Central City Locations? Journal of Regional Science, 46, 97-120. https://doi.org/10.1111/j.0022-4146.2006.00434.x

Bhatta, B. (2010). Causes and consequences of urban growth and sprawl. In Analysis of urban growth and sprawl from remote sensing data (pp. 17-36). Springer Berlin Heidelberg. https://doi.org/10.1007/978-3-642-05299-6_2

Crow, H. (2010). Factors Influencing Rural Migration Decisions in Scotl \&: An Analysis of the Evidence. Scottish Government Social Research.

Danejo, B. U., Abubakar, L. U., Haruna, M. A., Usman, R. A., \& Bawuro, B. M. (2015). Socio-Economic Factors Influencing Rural-Urban Migration in Wukari Local Government Area of Taraba State, Nigeria.

Gans, H. J. (1968). Urbanism \& Suburbanism as Way of Life. In R. E. Pahl (Ed.), Readings 
in Urban Sociology, Pergamon. https://doi.org/10.1016/B978-0-08-013293-8.50010-5

Government of Pakistan, (2017). Economic Survey of Pakistan 2016-17. Ministry of Finance, Islamabad, Pakistan.

Hosmer, Jr., D. W., Lemeshow, S., \& Sturdivant, R. X. (2013). Applied Logistic Regression. John Wiley \& Sons. Hoboken, New Jersey, United States. https://doi.org/10.1002/9781118548387

Ishfaq, S., Ahmed, V., Hassan, D., \& Javed, A. (2017). Internal Migration \& Labour Mobility in Pakistan. South Asia Migration Report. http://hdl.handle.net/11540/7227

Kainth, G. S. (2010). Push \& Pull Factors of Migration: A Case of Brick Kiln Industry of Punjab State. Asia-Pacific Journal of Social Sciences, 1, 82-116.

Khan, J. H., Hassan, T., \& Shamshad. (2011). Socio-economic causes of rural to urban migration in India. Asia Pacific J. of Soci. Sci. 2, 138-158

Lagakos, D., Mobarak, A. M., \& Waugh, M. E. (2017). The Welfare Effects of Encouraging Rural-Urban Migration (No. w24193). National Bureau of Economic Research.

Lerman, S. (1975). A Disaggregate Behavioural Model of Urban Mobility Decisions. Center for Transportation Studies Report, Massachusetts Institute of Technology, Cambridge.

Lewis, S. (2015). Qualitative inquiry \& research design: Choosing among five approaches. Health promotion practice, 16(4), 473-475. https://doi.org/10.1177/1524839915580941

Melo, G., \& Ames, G. (2016). May. Driving Factors of Rural-Urban Migration in China. In 2016 Annual Meeting, July 31-August 2, 2016, Boston, Massachusetts (No. 235508). Agricultural \& Applied Economics Association.

Mora, J., \& Taylor, J. E. (2006). Determinants of migration, destination, \& sector choice: Disentangling individual, household, \& community effects. International migration, remittances, \& the brain drain, 21-52.

Naseer, A. (2016). Current Status and Key Trends in Agricultural Land Holding and Distribution in Punjab, Pakistan: Implications for Food Security. Journal of Agricultural Studies, 4(4), 14-27. https://doi.org/10.5296/jas.v4i4.9670

Pakistan Bureau of Statistics, (2017). Provisional Province Wise Population by Sex \& Rural/Urban of 6th Population \& Housing Census of Pakistan 2017.

Reda, M. A., Hohfeld, L., Jitsuchon, S., \& Waibel, H. (2012). Rural-urban migration \& employment quality: A case study from Thailand. Asian Development Bank 6 ADB Avenue, Mandaluyong City 1550 Metro Manila, Philippines. https://doi.org/10.2139/ssrn.2103965

Regmi, A. (2014). The push-pull effects of urbanization on agriculture. Reviving drylands dialogue: bridging policy and research. News from CGIAR System Organization June 18, 2014.

Tacoli, C., McGranahan, G., \& Satterthwaite, D. (2015). Urbanisation, rural-urban migration \& urban poverty. Human Settlements Group, International Institute for Environment \& Development. URL: http://pubs.iied.org/10725IIED 


\section{Copyright Disclaimer}

Copyright for this article is retained by the author(s), with first publication rights granted to the journal.

This is an open-access article distributed under the terms and conditions of the Creative Commons Attribution license (http://creativecommons.org/licenses/by/3.0/). 